\title{
CHARLES MORLEY
}

\section{Czartoryski as a Polish Statesman}

When one thinks of Poland in the nineteenth century, the revolutions of 1830 and 1863 come immediately to mind. Yet not all Poles believed that the problem of the relations between Poland and Russia could be resolved only by revolution. There were many who preferred reconciliation. The number in the one camp as against the other at any particular time was a direct reflection of the political atmosphere in Russia. Whenever conditions gave rise to hopes for liberalization and reform among the Russians themselves, the policy of reconciliation would gain adherents among the Poles. This was the case under Alexander I, at the beginning of Alexander II's reign, and following the revolution of 1905.

In the period of Alexander I it was Prince Adam Jerzy Czartoryski (1770-1861) who emerged as the leading exponent of the policy of reconciliation. ${ }^{1}$ Like Wielopolski and Dmowski who came later, Prince Adam believed that Poles and Russians could live amicably together. The constitutional framework in which he envisioned the harmonious togetherness of the two peoples was an autonomous kingdom of Poland within the Russian Empire. That such a kingdom could be established was no idle dream, for the young Grand Duke Alexander was obsessed with constitutional ideas and was most favorably disposed toward the Poles. Czartoryski, who became a close friend and adviser of Alexander immediately after his arrival in St. Petersburg, was happy to learn of the grand duke's pro-Polish sentiments, and did everything possible to encourage them.

1. The only full-length biography in English is Marian Kukiel's Czartoryski and European Unity, 1770-1861 (Princeton, 1955). In Polish the outstanding work is the posthumous biography by Marceli Handelsman, Adam Czartoryski, 3 vols. in 4 (Warsaw, 1948-50, prepared for publication by Stefan Kieniewicz). Professor of European history at the University of Warsaw, Handelsman began at the outbreak of World War II to set down in writing the results of twenty-five years of research. In the first bombardment of Warsaw he lost some of his notes and several volumes of Czartoryski's correspondence borrowed from the Czartoryski Library of the National Museum in Cracow. Because he was Jewish he constantly had to hide from the Nazis. He found he could not write during the invasion and fall of France. But he returned to his task later that summer and even learned to type (he was almost sixty) to expedite his writing. Just before his arrest in the summer of 1944 he completed his manuscript, had it microfilmed, and buried the manuscript in his garden. Handelsman died in the Nazi concentration camp at Nordhausen on March 20,1945, but both manuscript and microfilm survived the war. 
These sentiments were soon to result in benefits to Poland and the Poles, for early in 1801 Grand Duke Alexander became the tsar of Russia. One of Alexander's first official acts was to recall Czartoryski from Italy to become a member of the tsar's intimate circle of advisers. ${ }^{2}$ While he counseled the tsar as a Russian subject, Czartoryski remained at heart a Pole and took advantage of his position to assist his compatriots and to serve his native land. Poles were released from prison and from Siberia; they returned freely to Russia from abroad; their lands were restored to them; many of them replaced Russian officials in high administrative posts in the Polish provinces. Writing in his memoirs of those first years of Alexander's reign, Prince Adam stated, "The days of persecutions, of trials, of political inquests, of sequestrations and confiscations, of suspicion and precaution had passed."

For more than twenty years (1803-24) Czartoryski occupied the post of curator of the University of Wilno. He was responsible not only for the university but for education in general in the eight Polish provinces of Russia, for these were included in the Wilno Educational District. The university, which was exclusively Polish, was of special concern to him, for he was convinced that a nation in political captivity must preserve its cultural identity. "He defended its budget, selected its professors, cared about the curriculum, and worried about its students," according to Marceli Handelsman, whose fourvolume posthumous biography of Czartoryski has contributed so much to our knowledge of the Polish statesman. ${ }^{4}$ When an investigation in 1823 revealed secret societies and political activities among the students, Czartoryski pleaded their cause and the freedom of the university with both the Grand Duke Constantine and Alexander. The number of schools, especially at the parish level, multiplied, and Czartoryski claimed that "the whole surface of Poland was covered with schools in which Polish consciousness [le sentiment polonais] had full liberty to develop." Some time later Novosiltsev complained that Czartoryski's activities as curator would delay the Russification of Poland's eastern borderlands by an entire century. ${ }^{\circ}$

Prince Adam's efforts on behalf of Poles, their properties, their jobs, and their schools were all steps toward the ultimate goal-the restoration of the kingdom of Poland. The achievement of this goal became a distinct possibility

2. To disrupt the close relations that had developed between Czartoryski and the Grand Duchess Elizabeth, Paul appointed the handsome Polish prince as minister to the king of Sardinia. According to Handelsman, Elizabeth was for Czartoryski "la seule grande passion de sa vie." See Handelsman, Czartoryski, 1:33; also Sergei P. Melgunov, Dela i liudi aleksandrovskogo vremeni (Berlin, 1923), pp. 103-4.

3. Charles de Mazade, ed., Mémoires du prince Adam Czartoryski et sa correspondance avec l'empereur Alexandre Ior, 2 vols. (Paris, 1887), 1:288.

4. Handelsman, Czartoryski, 1:58-59.

5. Mémoires de Czartoryski, 1:326.

6. Szymon Askenazy, Eukasiniski, 2 vols. (Warsaw, 1908), 2:180. 
when, fantastic as it may seem, the Pole Czartoryski was appointed deputy foreign minister of Russia in 1802 and foreign minister in $1804 .{ }^{7}$ In the negotiations for the Third Coalition and the plans for the campaign of 1805 against Napoleon, Czartoryski made provision for the re-establishment of a kingdom of Poland. He made every effort to persuade Prussia to abandon her neutrality, for Prussia's joining the Coalition would greatly strengthen it and facilitate the movement of Russian troops westward. But since Prussia refused, Czartoryski's plan provided that Russian troops would invade Prussian Polish territories; the Poles would rise against their Prussian oppressors; the territories would be declared part of the new kingdom of Poland, incorporated in the Russian Empire, with Alexander as its king. Thus, Prince Adam's dream of a restored autonomous Poland within the bounds of the Russian Empire was about to be realized, and there was great elation among most Poles who were privy to these plans. But instead of going to Warsaw, where he would have been crowned and where elaborate festivites were being arranged, Alexander journeyed to Berlin, where he vowed eternal friendship for the Prussian monarch at the tomb of Frederick the Great.

Several factors explain Alexander's unexpected conduct. He allowed Russian foreign policy to be influenced by his close personal attachment to the Prussian royal family. Napoleon's violation of Prussian neutrality by sending his troops through Ansbach made Frederick William more receptive to the idea of joining the Third Coalition. Many Russian leaders opposed Czartoryski's plans. But above all, a fatal weakness in Alexander's character, his indecisiveness, accounts for what he did. "As we approached the hour of decision, ... his resolution grew weaker," wrote Czartoryski. ${ }^{8}$ The tsar feared an armed conflict with the Prussians; he preferred to have them on his side rather than against him in his confrontation with Napoleon. ${ }^{9}$

A few months later Czartoryski resigned from the foreign ministry. But despite the failure of his plans and the additional blow dealt to his dreams by the creation of the Duchy of Warsaw under Napoleon, Czartoryski remained faithful in his friendship and allegiance to Alexander. His fidelity was sorely tested during the events of 1812. In the early days of the invasion an Extra-

7. Czartoryski claimed that his appointment to the Foreign Ministry was the result of "one of those whims of which he [Alexander] had so many. He would not rest until it was satisfied" (Mémoires de Czartoryski, 1:360). When Czartoryski reminded the tsar that their views on foreign policy might differ, especially with regard to Poland, Alexander replied that on Poland their views were in complete agreement and that if they should ever be in conflict, Czartoryski would be free to resign.

8. Mémoires de Czartoryski, 1:398.

9. For the details of what is sometimes called Czartoryski's Mordplan gegen Preussen and the reasons for its failure see Charles Morley, "Alexander I and Czartoryski: The Polish Question from 1801 to 1813," Slavonic and East European Review, 25 (April 1947): 407-11; also Kukiel, Czartoryski and European Unity, chap. 5. 
ordinary Diet of the Duchy of Warsaw, headed by Prince Adam's father, proclaimed the re-establishment of Poland and called upon Poles everywhere to rally behind it. Torn between his loyalty to the tsar and his sentiments as a patriotic Pole, Prince Adam found himself literally at the crossroads of his life. At first he shut himself up in one of his villages (Sieniawa, in Galicia) and then traveled to Carlsbad and Vienna. He wished to be far enough removed from his homeland to avoid "involvement in the war, yet close enough to be informed of everything accurately and quickly."10 In his dilemma he sought the advice of his mother, with whom his ties at that time were still very close. She wrote, "Do what honor strictly commands. Providence takes care of everything, but the present moment is difficult. ... Ultimately, the time will come when, following the impulse of your heart, you will be able to come here [to Warsaw] and together with us declare ' $I$ am in Poland, I am a Pole, Poland exists, we have our Fatherland." "11 Unable to remain silent and inactive in the face of developments in his homeland, Czartoryski pleaded with Alexander to release him from his allegiance to the tsar and Russia: "Poland has been solemnly proclaimed by a General Confederation, at the head of which my father has been placed. The name of Poland falls from his lips, and once pronounced, becomes decisive for me."12

Prince Adam made several appeals to the tsar for permission to leave the Russian service. Fortunately for the future of Poland, some of these never reached the tsar and others remained unanswered. Thus even the war did not rupture the bonds of friendship between the Polish patriot and the Russian monarch. As the Grand Army with its large Polish contingent retreated and the Russian forces approached the Polish frontiers, Poles now looked toward Prince Adam as the one man who might rescue Poland from utter destruction. Thanks to his unceasing efforts and also to the fact that Alexander's original sentiments toward the Poles had not changed, Czartoryski achieved his life's dream for Poland-an autonomous kingdom within the Russian Empire. ${ }^{13}$

10. Handelsman, Czartoryski, 1:80.

11. Letter of June 3, 1812. See Handelsman, Czartoryski, 1:43-44. Translation never quite conveys the sentiment of the original: "Jestem w Polsce, jestem Polak, żyje Polska, mamy Ojczyzne.."

12. Letter of July 4, 1812. See Mémoires de Czartoryski, 2:288. That same day Czartoryski wrote a letter of farewell to his close friend, Count Paul Stroganov, for whom he professed continued friendship and which contained this perceptive observation: "You will be determined to destroy us. Hatred will mount on both sides to the highest degree and will not subside, perhaps, until one day, after much blood has been spilled, it will at last be realized that the happiness and glory of one of our two nations are not necessarily dependent on the enslavement and unhappiness of the other." See Grand Duke Nikolai Mikhailovich, Le Comte Paul Stroganov, 3 vols. (Paris, 1905), 2:270.

13. The first letter written by Alexander to Czartoryski since the outbreak of hostilities was dated January 13,1813. In this long epistle, which took two days to compose, Alexander reassured Czartoryski of his continued personal friendship and of his beneficent 
The years 1813-15 represent, in my judgment, the period of Czartoryski's greatest achievements as a Polish statesman. They represent the fulfillment of those aspirations for his homeland which he had held from the first days as a hostage at the court of Catherine the Great. To realize his hopes and dreams, Czartoryski re-established contact with his sovereign, pursued him into Germany and to Paris, accompanied him to England, and in Vienna, at the Congress, Czartoryski became Alexander's "chief of staff for Polish affairs." As the Polish question proved to be the chief stumbling block to the speedy reconstruction of Europe, Czartoryski had a most difficult task to perform. In the conduct of diplomacy he certainly excelled, and he used his great talents and his numerous friends among the European statesmen to secure what was, under the circumstances, the only possible resolution of the Polish question. The Napoleonic Duchy of Warsaw, somewhat reduced in size, was transformed into a small kingdom of Poland, united to the Russian Empire and with Alexander as its king. ${ }^{14}$ Prince Adam prepared the principles which were to be embodied in the constitution and which were to serve as an "immutable rule and as instructions for the new provisional government."15 $\mathrm{He}$ was appointed one of the five members of the provisional government. In reality Czartoryski headed the provisional administration, drafted its constitution, and organized the new state. This constitution of the kingdom of Poland stands as a memorial to Czartoryski's character and statesmanship. It guaranteed civil rights and numerous privileges to the Poles, gave large numbers an opportunity to participate in the legislative and administrative processes, and made the state an autonomous entity united to the Russian Empire. The Congress Kingdom had its own organs of government, including a two-chamber diet, its own army, and its own flag. Polish was the language of the administration, the courts, and the

intentions toward Poland and the Poles. The reader will be interested in the following excerpts from this letter: "Success . . . has in no way altered my sentiments nor my intentions toward Poland. ... Vengeance is a sentiment unknown to me and my greatest pleasure is to repay evil with good. . . . All the Russian generals have received orders to treat the Poles as friends and brothers. ... I place complete confidence in you and my sentiments of attachment are pledged irrevocably to you." For the complete text of this letter see Mémoires de Czartoryski, 2:302-8.

14. The details of this agreement were incorporated into treaties signed by Russia, Austria, and Prussia on May 3, 1815, the anniversary of the Constitution of 1791 and an important Polish national holiday. Identical provisions were later embodied in the Final Act of the Congress of Vienna. Since so many historians have written on the Polish question and the peace settlement of 1815, the author has deliberately excluded any discussion of the problem. Interested English readers may wish to consult the writings of C. K. Webster and Harold Nicolson and chap. 12 of Cambridge History of Poland, vol. 2. The following works in Polish deserve to be cited: Kazimierz Bartoszewicz, Utworzenie Królestwa Kongresowego (Cracow, 1916) and Eugeniusz Wawrzkowicz, Anglia a sprowa polska, 1813-1815 (Warsaw, 1917).

15. These principles are summarized in Handelsman, Czartoryski, 1:112-13. 
educational system. No country in Europe enjoyed at that time as liberal a constitution as the Polish one. ${ }^{16}$

When the new constitution was promulgated on November 27, 1815, and the newly created kingdom officially launched, Czartoryski, to his own surprise and to that of most Poles, was not appointed viceroy. He emerged from a midnight conference with Alexander in the Royal Palace in Warsaw quite shaken and confused, and walked for more than a quarter of an hour in the corridors, without greeting or noticing anyone. ${ }^{17}$ Shortly after, he noted in his diary that his job was done-he had re-established a "poor Poland" on "rather unstable feet." "Let others now work" for the fatherland. ${ }^{18}$

Henceforth, Czartoryski spent more time on his ancestral estates at Puławy. He even found time for marriage. At forty-seven he married the Princess Anna Sapieha, age eighteen. But as a senator and a member of the Administrative Council of the kingdom of Poland, which he was so largely responsible for creating, he could not remain indifferent to developments in the kingdom. In fact, the defense of rights and privileges of his country and his compatriots from abuse by Russian authorities became his principal concern during the rest of his days in Poland.

Prince Adam now met with Alexander only rarely, but he continued to write frequently, bringing to the monarch's attention the activities of the Grand Duke Constantine and Novosiltsev and the violations of the Polish constitution. When he met with Alexander for the last time at the height of the University of Wilno crisis, resulting from the discovery of secret student societies, he spoke frankly and courageously: "The whole nation feels that Your Imperial Majesty no longer has good will toward it. The nation has lost its confidence in Your sentiments. The people fear that all You have given them will be destroyed and perceive this destruction in acts of violence already committed."19 Czartoryski

16. Bohdan Winiarski, Ustrój polityczny ziem polskich w XIX wieku (Poznań, 1923), pp. 95-117; Szymon Askenazy, Rosya-Polska, 1815-1830 (Lwów, 1907), pp. 68-74. For the complete text of the constitution in Russian, French, and Polish see N. D. Sergeevsky, Konstitutsionnaia khartiia 1815 goda $i$ niekotorye drugie akty byvshago Tsarstva Pol'skago, 1814-1881 (St. Petersburg, 1907), pp. 17-108. At the opening session of the Diet of 1818, Alexander expressed the hope of extending the "beneficial influence" of the liberal institutions he had granted to Poland "to all the countries which Providence has entrusted to my care." See N. K. Shilder (Schilder), Imperator Aleksandr Pervyi, ego zhizn' i tsarstvovanie, 2nd ed., 4 vols. (St. Petersburg, 1904-5), 4:86.

17. Shilder, Imperator Aleksandr Pervyi, 3:356; Handelsman, Czartoryski, 1:116. For several valid reasons Alexander felt that the Grand Duke Constantine had to remain in Warsaw. Because of Czartoryski's great hostility toward the grand duke, Alexander could not appoint Prince Adam viceroy of the new kingdom.

18. Kukiel, Czartoryski and European Unity, p. 135; Handelsman, Czartoryski, $1: 116-17$.

19. The meeting took place in October 1823 in Wolosowice. See Szymon Askenazy, Szkice i portrety (Warsaw, 1937), p. 282. 
was relieved of his curatorship of the university, and Novosiltsev was soon appointed in his place.

The difficulties between Poland and Russia which began under Alexander multiplied and intensified under his successor. Within five years of Nicholas's accession to the throne, they culminated in the November Uprising of 1830. A prelude to the events of 1830 was the trial of the Polish Decembrists in Warsaw. Their case, in accordance with the kingdom's constitution but contrary to the wishes of the Grand Duke Constantine, came before the Senate, constituted as a high court. Here Czartoryski actually determined the course and outcome of the proceedings, for the president of the Senate and the other senators all looked to him for guidance. The high court ruled that the conspirators, as subjects of the kingdom of Poland, could not be guilty of high treason against Russia. Five of the conspirators were declared guilty of lesser crimes and received minor sentences; the remaining three were found completely innocent. Both Constantine and Nicholas were infuriated by the verdict, and Nicholas even tried to have it reversed in the Administrative Council. Here Czartoryski and others vigorously defended the decision, which Nicholas ultimately confirmed. The whole affair revealed the deep cleavage that had developed between the tsar and his Polish subjects. ${ }^{20}$

At the very height of the debate in the Administrative Council Peter Wysocki and a few students at the Military Academy in Warsaw organized the Cadet League, thus initiating the movement that led directly to the November Uprising. Because Czartoryski had played the leading role in defending the Polish constitution, the self-government of the kingdom, and the rights of its inhabitants, the revolutionaries turned to him for leadership in the tragic events of $1830-31$. Yet Prince Adam was hardly a revolutionary, and war with Russia was furthest from his thoughts. Several months before the Night of November (November 29, 1830, the outbreak of the revolution), Czartoryski tried to apprise the monarch of the realities of the situation in the kingdom. Reference here is to the "Remarks" of the Senate of 1830, prepared under the guidance of Czartoryski. The "Remarks" amounted to a critical review of the entire period of the Congress Kingdom, with emphasis on the last five years, and an appeal to the king "for a return to legality, for the introduction of indispensable reforms."21 When, after the July Revolution in

20. For details on the Polish Decembrists (Patriotic Society) see Askenazy, RosyaPolska, pp. 109-14, and Polska, jej dzieje i kultura (Warsaw, 1927-32), 3:128-30; for documentary material see Stanisław Smolka, Korrespondencya Lubeckiego, 4 vols. (Cracow, 1909), vols. 3 and 4.

21. Practically no aspect of life in the kingdom was omitted from the "Remarks" (Uwagi). They dealt with government and administration, the judicial system and law codification, the budget, the economy, education and religion, the Jewish problem, and, above all, the peasants. The "Remarks" charged that in fifteen years the government of 
Paris, the pace of events in Warsaw gained momentum, Czartoryski cautioned the revolutionaries to exercise restraint and to await developments in the West. Even after the attack on the Belvedere Palace and the escape of the Grand Duke Constantine, Prince Adam attempted to reconcile the opposing forces. Later he endeavored to forestall the dethronement of Nicholas I.22 Although he failed in his efforts at prevention and reconciliation, he did not turn his back on what had happened: he accepted the leadership of the Provisional Revolutionary Government and later of the National Government.

Whatever deficiencies Czartoryski may have possessed for the effective fulfillment of his new role, excess of imagination was certainly not one of them. He had no illusions about Poland's military strength or about armed assistance from abroad. He was aware that the revolution broke out at the worst possible time-at the very moment when all the forces of the empire were marching toward the Polish frontiers "to bring to reason the revolutionaries of France and Belgium." ${ }^{23}$ As an experienced diplomat with influential connections in the important capitals of Western Europe, he exerted great efforts to secure foreign intervention. Yet he realized that successful diplomacy could result only from actual or potential military success. Prince Adam did provide inspiration to the troops and moral support to the military leaders. At times he even suggested military strategy. But the odds were against the Poles on the battlefields, and the international situation was not conducive to intervention on their behalf. ${ }^{24}$

Lack of military success caused endless dissension within the National Government and much public opposition to it. The opposition culminated in the revolutionary outburst of August 15, 1831, the collapse of the National Government, and the end of Czartoryski's career as a Polish statesman. He continued to serve the Polish cause for another thirty years, but now as an exile in France, far from his native land.

One must certainly conclude that Prince Adam Czartoryski was a leading

the kingdom had failed to take a single, small step to improve the lot of the peasantry. For a summary of the "Remarks" see Handelsman, Czartoryski, 1:140-43.

22. In the bitter debate in the Diet on January 25, 1831, Czartoryski advised that the dethronement resolution be sent to committee for consideration. Instead, the resolution was adopted immediately by acclamation. See Michal Rostworowski, Dyaryusz Sejmu $z \mathrm{r}$. 1830-1831, 6 vols. (Cracow, 1907-12), 1:243-45; see also R. F. Leslie, Polish Politics and the Revolution of November 1830 (London, 1956), pp. 156-57.

23. Words of General Benckendorff to a Polish delegation. See Charles Morley, "The European Significance of the November Uprising," Journal of Central European Affairs, 11, no. 4 (January 1952) : 415.

24. For details of Czartoryski's activities in 1830-31 see Walentyna Nagórska-Rudzka, "Książe Adam Czartoryski w dobie powstania listopadowego," Przegląd Historyczny, 29 (1930-31): 210-308. The diplomacy of the period is analyzed by Józef Dutkiewicz in Francja a Polska w 1831 r. (Eódź, 1950) and in Anglia a sprawa polska w latach 1830

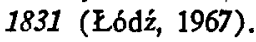


Polish statesman during the first thirty years of the nineteenth century. In most events of this period he was deeply involved and his role was significant. Yet, curiously enough, his career was strewn with many failures, and his ultimate goal remained always just beyond his reach. He planned Poland's re-establishment during the war of the Third Coalition (1805), but his plans were frustrated. He fully expected to be named viceroy of the kingdom of Poland (1815), only to be disappointed in his expectations. He tried in vain to secure the removal of the Grand Duke Constantine from Warsaw. The revolution and the war of 1830-31 broke out despite his opposition. He never ceased suggesting that the "lost provinces," the territories annexed by Russia in the three partitions, should be reunited with the kingdom of Poland, but they never were. A united Poland in union with Russia and enjoying all the rights and privileges of an independent state-this was his ultimate goal. Unfortunately he was never able to achieve it. ${ }^{25}$

25. When elected president of the National Government on January 30, 1830, Czartoryski included the following statement in his acceptance speech: "It was my conviction that Poland, remaining attached to a people of like race . . . could with certainty regain in the end her unity, regain all of the attributes and rights of independence. All of my actions were based on and guided by this conviction." See Rostworowski, Dyaryusz Sejmu, 1:386. 